\title{
PENGARUH KOMPETENSI DAN EQ TERHADAP KINERJA PEGAWAI KANTOR BAPPEDA PROVINSI SULAWESI TENGAH
}

\author{
Taufik \\ Lina Mahardiana \\ Risnawati \\ Program Studi Manajemen S1, Fakultas Ekonomi Dan Bisnis Universitas Tadulako \\ Email : Taufikhapit@gmail.com`
}

\begin{abstract}
Abstrack
The purpose of research is to find out the influence of competence, and the Emotional Intelligence on the Performance of Employees in the Office of Planning and Regional Development Planning (BAPPEDA), both in an effort to be partial and partial. This research was conducted in Palu City. In the Office of the Regional Development Planning Agency (BAPPEDA) of Central Sulawesi Province by using 65 samples as multiple research respondents. Interviews, observations, and questionnaires are collectors of data collection techniques in this research. Based on the analysis of known knowledge and a partial it was observed that the variable competence and emotional intelligenci significant a influence on employee performance.
\end{abstract}

\begin{abstract}
Abstrak
Tujuan dari penelitian ini adalah mengetahui pengaruh kompetensi, dan Kecerdasan Emosional Terhadap Kinerja Pegawai Kantor Badan Perencanaan Pembngunan Daerah (BAPPEDA) baik secara serempak maupun secara parsial. Penelitian ini dilakukan di Kota Palu Pada Kantor Badan Perencanaan Pembangunan Daerah (BAPPEDA) Provinsi Sulawesi Tengah dengan menggunakan 65 sampel sebagai responden penelitian. Wawancara, observasi, dan kuesioner merupakan pengumpulan teknik pengumpulan data dalam penelitian ini Berdasarkan hasil analisis diketahui bahwa secara serempak maupun parsial variable kompetensi dan kecerdasan emosional berpengaruh signifikan terhadap kinerja pegawai.
\end{abstract}

Kata Kunci : kompetensi, kecerdasan emosional, dan kinerja

\section{PENDAHULUAN}

Perkembangan Ilmu Pengetahuan dan Teknologi dan derasnya arus globalisasi telah membawa perubahan-perubahan dan menciptakan paradigma baru di tempat kerja maupun di dunia pendidikan. Oganisasi tidak hanya semata-mata mengejar pencapaian produktivitas yang tinggi saja, tetapi juga lebih memperhatikan kinerja dalam proses pencapaiannya. Dengan demikian kinerja (performance) merupakan faktor kunci bagi setiap individu dan organisasi dalam pencapaian produktivitas. Kinerja adalah suatu hasil dimana orang, sumber-sumber yang ada di lingkungan kerja tertentu secara bersama membawa hasil akhir yang didasarkan tingkat mutu dan standar yang telah ditetapkan. Penelitian Goleman dalam T Hermaya (2006) mengungkapkan bahwa kecerdasan otak hanya menyumbang kirakira $20 \%$ bagi faktor-faktor yang menentukan sukses dalam hidup, dan yang $80 \%$ lainnya diisi oleh kekuatan-kekuatan lain, termasuk kecerdasan emosional yang meliputi kemampuan untuk memotivasi diri dan bertahan, menghadapi frustrasi, mengendalikan dorongan hati dan tidak melebih-lebihkan kesenangan, mengatur suasana hati dan menjaga beban stress agar tidak melumpuhkan kemampuan berfikir, berempati dan berdoa, Konsekuensi dari pelaksanaan Undang-Undang tersebut adalah penyelenggaraan pemerintahan, pembangunan dan pelayanan kepada masyarakat.Salah satu aspek penting dalam upaya peningkatan kinerja Pemerintah Daerah adalah melalui kebijakan perencanaan pembangunan daerah yang berkualitas dan berkesinambungan. Hal ini didukung oleh Undang-Undang 
Nomor 25 Tahun 2004 tentang Sistem Perencanaan Pembangunan Nasional, yang menyebutkan bahwa perencanaan pembangunan nasional maupun daerah terdiri dari perencanaan pembangunan jangka panjang, perencanaan pembangunan jangka menengah dan perencanaan pembangunan tahunan.

Badan Perencanaan Pembangunan Daerah (BAPPEDA) Provinsi Sulawesi Tengah adalah lembaga yang memiliki tugas dan fungsi membantu gubernur dalam penyelenggaraan pemerintahan Provinsi dalam lingkup perencanaan dan pengendalian pembangunan.Organisasi ini dituntut untuk menghasilkan kinerja baik secara individual maupun secara kelompok. Berdasarkan penelitian awal yang dilakukan, melalui wawancara yang dilakukan dengan bapak Affan sebagai Kepala Bagian Data pada hari jumat tanggal 14 April 2017 pukul 10:00- 11:00, ditemukan berbagai permasalahan yang sering dihadapi di Badan Perencanaan Pembangunan Daerah (BAPPEDA).sebagai institusi perencana pembangunan di Provinsi Sulawesi Tengah harus dapat menjadi contoh bagi Organisasi Perangkat Daerah lain.Olehnya, aparatur BAPPEDA dituntut untuk memiliki pengetahuan, pemahaman, dan penguasaan tentang perencanaan pembangunan termasuk penyusunan indikator program dan kegiatan. Pemahaman tentang indikator yang smart dan akuntabel inilah yang masih menjadi permasalahan.

\section{KAJIAN LITERATURE DAN PENGEMBANGAN HIPOTESIS Kompetensi}

Secara Harfiah, Kompetensi berasal dari kata competence yang artinya kecakapan, kemampuan dan wewenang (Scale,1975) dikutip oleh Sutrisno (2009). Secara Etimologi, kompetensi diartikan sebagai dimensi perilaku keahlian atau keunggulan seorang pemimpin atau staff yang mempunyai keterampilan, pengetahuan, dan perilaku yang baik. Wibowo $(2007 ; 67)$ menyatakan kompetensi adalah suatu kemampuan untuk melaksanakan atau melakukan suatu pekerjaan yang dilandasi atas keterampilan dan pengetahuan serta didukungoleh sikap kerja yang dituntut oleh pekerjaan tersebut. Spencer dan Spencer dalam Palan (2007:84) mengemukakan bahwa kompetensi menunjukkan karakteristik yang mendasari perilaku yang menggambarkan motif, karakteristik pribadi (ciri khas), konsep diri, nilai-nilai, pengetahuan atau keahlian yang dibawa seseorang yang berkinerja unggul (superior performer) di tempat kerja.

\section{Komponen Kompetensi}

Menurut Moeheriono (2012;95) Kompetensi seseorang sangat besar dapat dipengaruhi oleh beberapa faktor, baik dari dalam (internal) maupun dari luar (eksternal), yaitu terdiri antara lain sebagai berikut

a) Bakat bawaan, bakat yang sudah ada dan melekat sejak mereka dilahirkan.

b) Motivasi kerja yang tinggi.

c) Sikap, motif, dan nilai cara pandang.

d) Pengetahuan yang dimiliki baik dari pendidikan formal maupun non formal (pelatihan, course, panel dan lain-lain)

e) Keterampilan atau keahlian yang dimiliki.

f) Lingkungan hidup dari kehidupan mereka sehari-hari.

\section{Kecerdasan Emosional}

Dalam buku Emotional Intelligence, Daniel Goleman mengemukakan bahwa kecerdasan emosi merupakan sisi lain kecenderungan kognitif yang berperan dalam aktifitas manusia, yang meliputi kesadaran diri dan kendali diri, semangat dan motivasi diri serta empati dan kecakapan sosial. Kecerdasan emosi lebih ditujukan kepada upaya mengendalikan, memahami dan mewujudkan emosi agar terkendali dan dapat dimanfaatkan untuk memecahkan masalah kehidupan, terutama yang terkait dengan kehidupan manusia. Menurut Goleman dalam ( T Hermaya 2006), kecerdasan emosional adalah kemampuan mengenali perasaan kita sendiri dan perasaan orang lain, kemampuan memotivasi diri sendiri, dan kemampuan mengelola emosi dengan baik pada diri sendiri dan dalam hubungan orang lain. Kemampuan ini saling berbeda dan melengkapi dengan kemampuan akademik murni, yaitu kognitif murni yang diukur dengan IQ. Sedangkan menurut Cooper dan Sawaf (2002), kecerdasan emosional adalah kemampuan merasakan, memahami, dan secara efektif menerapkan dan kepekaan emosi sebagai sumber energi, informasi, koneksi, dan pengaruh yang manusiawi. 


\section{Landasan Kecerdasan Emosional}

Menurut Paton (2000), dasar kecerdasan emosional adalah memiliki kesadaran untuk mempertahankan harga diri dan citra diri. Dua hal ini mempengaruhi bagaimana kita merasa dan bertindak, baik dalam kehidupan pribadi maupun dalam karir. Mereka yang tidak sadar akan kemampuan-kemampuannya atau yang mempunyai pikiran sesat terhadap dirinya sendiri, biasanya hidup dalam kehampaan atau kekosongan.

Harga diri adalah penghargaan terhadap keunikan penampilan fisik, kemampuan-kemampuan intelektual, kecakapan-kecakapan pribadi, dan kepribadian. Harga diri merupakan parameter yang membedakan kita dari orang lain sebagai individu. Sedangkan citra diri adalah refleksi apa yang kita lihat dalam diri sendiri. Potret diri kita terpapar dengan kedalaman, pewarnaan, pencahayaan, dan bayangan yang bisa saja menerangi, menipu, atau pun mengkaburkan harapan sendiri

\section{Kinerja}

Kinerja atau performance adalah hasil kerja yang dapat dicapai oleh seseorang atau sekelompok orang dalam suatu organisasi, sesuai dengan wewenang dan tanggung jawab masing-masing, dalam rangka upaya mencapai tujuan organisasi bersangkutan secara legal, tidak melanggar hukum dan sesuai dengan moral maupun etika (Suyadi Prawirosentono 2008).

Kinerja pegawai (prestasi kerja) adalah hasil kerja secara kualitas dan kuantitas yang dicapai oleh seseorang pegawai dalam melaksanakan tugasnya sesuai dengan tanggung jawab yang diberikan kepadanya (Anwar Prabu Mangkunegara, 2005).

Berbagai pendapat diatas dapat menggambarkan bahwa kinerja pegawai dan kinerja organisasi memiliki keterkaitan yang sangat erat, tercapainya tujuan organisasi tidak bisa dilepaskan dari sumber daya yang dimiliki oleh organisasi yang digerakkan atau dijalankan pegawai yang berperan aktif sebagai pelaku dalam upaya mencapai tujuan organisasi. Jadi dapat disimpulkan bahwa kinerja pegawai adalah penilaian hasil kerja seseorang dalam suatu organisasi dengan tugas dan tanggung jawabnya dalam rangka mencapai tujuan organisasi.

\section{Indikator kinerja pegawai}

Terdapat berbagai teori mengenai indikator kinerja pegawai. Salah satunya indikator kinerja pegawai menurut Muhammad Fadel (2009). Ia mengemukakan beberapa indikator yang digunakan untuk mengukur kinerja pegawai yaitu:

1. Pemahaman atas tupoksi

Dalam menjalankan tupoksi, bawahan harus terlebih dahulu paham tentang tugas pokok dan fungsi masing-masing serta mengerjakan tugas sesuai dengan apa yang menjadi tanggung jawabnya.

2. Kecepatan kerja

Dalam menjalankan tugas kecepatan kerja harus diperhatikan dengan menggunakan mengikuti metode kerja yang ada.

3. Keakuratan kerja

Tidak hanya cepat, namun dalam menyelesaikan tugas karyawan juga harus disiplin dalam mengerjakan tugas dengan teliti dalam bekerja dan melakukan pengecekan ulang

\section{Hubungan Antar Variabel}

\section{Hubungan kompetensi dan kecerdasan emosional terhadap kinerja}

Kompetensi dan kecerdasan emosional memiliki pengaruh yang signifikan terhadap kinerja. Kompetensi dan kecerdasan emosional menjadi factor yang mempengaruhi kinerja pegawai diluar dari faktor-faktor lainnya. Kompetensi dan kecerdasan emosional yang dimiliki oleh setiap pegawai harus baik agar dapat mempengaruhi kinerja yang akan dihasilkan, jika hanya hanya kompetensi saja yang baik tetapi tidak diikuti dengan kecerdasan emosional yang baik pula maka kinerja yang dicapai juga tidak maksimal, begitupun sebaliknya. Hal ini didukung dengan hasil penelitian yang dilakukan oleh I Gusti Ngurah Karmandita dan Made Subudi dengan judul penelitian Pengaruh Kompetensi Dan Kecerdasan Emosional Terhadap Kinerja Karyawan Si Doi Hotel Dan Restaurant Legian. 
Berdasarkan hasil penelitian diketahui bahwa secara simultan variable kompetensi dan kecerdasan emosional berpengaruh signifikan terhadap kinerja karyawan. Secara parsial variable kompetensi dan kecerdasan emosional berpengaruh positif dan signifikan terhadap kinerja karyawan "Si Doi" Hotel dan Restaurant Legian.

\section{Hubungan kompetensi dengan kinerja}

Menurut Spencer (1993) hubungan antara kompetensi pegawai dengan kinerja adalah sangat erat dan penting sekali, relevansinya ada dan kuat serta akurat, bahkan pegawai apabila ingin meningkatkan kinerjanya seharusnya mempunyai kompetensi yang sesuai dengan tugas pekerjaannya. Kompetensi dapat menyebabkan atau digunakan untuk memprediksi kinerja seseorang artinya jika mempunyai kompetensi yang tinggi, maka akan mempunyai kinerja yang tinggi pula.

Hal tersebut sejalan dengan penelitaian yang dilakukan Namira Mardin Amin (2015) dengan judul penelitian Pengaruh Kompetensi Terhadap Kinerja Pegawai Di Sekretariat Daerah Kabupaten Sidenreng Rappang. Hasil penelitian menunjukan bahwa variable kompetensi memiliki pengaruh simultan dan parsial terhadap kinerja pegawai.

\section{Hubungan Kecerdasan Emosional Dengan Kinerja}

Dunia kerja mempunyai berbagai masalah dantantangan yang harus dihadapi oleh karyawan, misalnya persaingan yang ketat, tuntutan tugas, suasana kerja yang tidak nyaman dan masalah hubungan dengan orang lain. Masalah-masalah tersebutdalam dunia kerja bukanlah suatu hal yang hanya membutuhkan kemampuan intelektualnya, tetapi dalam menyelesaikan masalah tersebut kemampuan emosi atau kecerdasan emosi lebih banyak diperlukan. Bila sesorang dapat menyelesaikan masalah-masalah di dunia kerja yang berkaitan dengan emosinya maka dia akan menghasilkan kerja yang lebih baik.

Hal ini sesuai dengan hasil penelitian yang dilakukan oleh McClelland, Hunter, dan Schmid (1973) dalam Goleman (2006) yang menunjukkan indikasi bahwa faktor dominan yang menentukan keberhasilan karir bukanlah kecerdasan otak, melainkan seperangkat kecerdasan lainnya yang kemudian dipopulerkan oleh Goleman sebagai kecerdasan emosional. Penelitian lebih lanjut yang dilakukan oleh McClelland (dalam Goleman, 2006) menyatakan bahwa kemampuan akademik bawaan, nilai rapor, dan predikat kelulusan pendidikan tinggi tidak memprediksi seberapa baik kinerja seseorang sesudah bekerja atau seberapa tinggi sukses yang dicapai selama hidup. Sebaliknya Mc.Clelland mengatakan bahwa seperangkat kecakapan khusus seperti empati, disiplin diri,dan inisiatif mampu membedakan orang-orang sukses dengan mereka yang hanya cukup baik untuk mempertahankan pekerjaan mereka.

\section{METODE PENELITIAN}

\section{Populasi, dan Teknik Penarikan Sampel}

Populasi adalah wilayah generalisasi yang terdiri atas: obyek/subyek yang mempunyai kualitas dan karakteristik tertentu yang ditetapkan oleh peneliti untuk dipelajari dan kemudian ditarik kesimpulannya (Sugiyono 2010). Populasi dalam penelitian ini adalah seluruh Pegawai Pada Kantor Badan Perencanaan Pembangunan Daerah (BAPPEDA) Provinsi Sulawesi Tengah sebanyak182 orang.

Sampel adalah bagian dari populasi Arikunto (2005). Sampel dari penelitian ini adalah sebagian dari populasi yang diambil sebagai sumber data dan dapat mewakili seluruh populasi. Penarikan sampel dalam penelitian ini menggunakan sampel secara acak (Random sampling). Adapun rumus yang digunakan untuk menentukan sampel penelitian, yaitu:

$n=\frac{\mathrm{N}}{\mathrm{N} \cdot \mathrm{d}^{2}+1}$ 


\section{Keterangan ;}

$$
\begin{aligned}
& \mathrm{n} \quad=\text { Jumlah sampel } \\
& \mathrm{N} \quad=\text { Populasi } \\
& \mathrm{d}=\text { presisi }(\text { ditetapkan10\%dengan tingkat kepercayaan 90\%) } \\
& n=\frac{\mathrm{N}}{N \cdot d^{2}+1} \\
& =\frac{182}{182 \cdot 0,1^{2}+1} \\
& =\frac{182}{182.0,01+1} \\
& =\frac{182}{1,82+1} \\
& n=\frac{182}{2,82}=64,53=65
\end{aligned}
$$

\section{Uji Instrumen Penelitian}

\section{Skala Pengukuran}

Skala pengukuran merupakan kesepakatan yang digunakan sebagai acuan untuk menentukan panjanag pendeknya interval yang ada dalam alat ukur, sehingga alat ukur tersebut bila digunakan dalam pengukuran akan menghasilkan data kuantitatif (Sugiyono, 2014). Sugiyono (2014) menyatakan bahwa skala likert digunakan untuk mengukur sikap, pendapat, dan persepsi seseorang atau sekelompok orang tentang fenomena sosial.

\section{Uji Validitas}

Validitas menurut Sugiyono (2016:177) menunjukan derajat ketepatan antara data yang sesungguhnya terjadi pada objek dengan data yang dikumpulkan oleh peneliti untuk mencari validitas sebuah item, kita mengkorelasikan skor item dengan total item-item tersebut. Jika koefisien antara item dengan total item sama atau diatas 0,3 maka item tersebut dinyatakan valid, tetapi jika nilai korelasinya dibawah 0,3 maka item terebut dinyatakan tidak valid. Jadi validitas ingin mengukur apakah pertanyaan dalam kuesioner yang sudah kita buat betul-betul dapat mengukur apa yang hendak kita ukur. Mengukur validitas dilakukan dengan dua cara:

1. Melakukan kolerasi antar skor butir pertanyaan dengan total skor konstruk atau variabel.

2. Uji validitas dapat juga dilakukan dengan melakukan korelasi bivariate antara masing-masing skor indikator dengan total skor konstruk.

Uji validitas dilakukan dengan 27 butir pernyataan yang disebarkan kepada 40 responden. Uji instrument penelitian ini dilakukan pada kantor Badan Kepegawaian Daerah (BKD) provinsi Sulawesi Tengah, untuk menguji apakah instrument penelitian tersebut layak untuk dilakukan. Berikut tabel hasil uji validitas instrument penelitian pada badan kepegawaian daerah (BKD) Provinsi Sulawesi tengah

\section{Uji Reliabilitas}

Menurut Ghozali, (2005:41) Reliabilitas sebenarnya adalah alat untuk mengukur suatu kuesioner yang merupakan indikator dari variabel atau konstruk.Suatu kuesioner dikatakan reliabel atau handal jika jawaban seseorang terhadap pernyataan adalah konsisten atau stabil dari waktu ke waktu.

Pengukuran reliabilitas dapat dilakukan dengan dua cara yaitu: 
1. Repeated Measure atau pengukuran ulang: Disini seseorang akan disodori pertanyaan yang sama pada waktu yang berbeda, dan kemudian dilihat apakah ia tetap konsisten dengan jawabannya.

2. One Shot atau pengukaran sekali saja. Disini pengukurannya hanya sekali dan kemudian hasilnya di bandingkan dengan pertanyaan lain atau mengukur korelasi antar jawaban pertanyaan. Spss memberikan fasilitas untuk mengukur reliabilitas dengan uji statistik Cronbach Alpha $(\alpha)$. Suatu konstruk atau variabel di katakan reliabel jika memberikan nilai Cronbach Alpha>0.60. berikut adalah tabel uji realibilitas instrument penelitian :

\section{Uji Asumsi Klasik}

\section{Uji Normalitas}

Menurut Ghozali (2005) uji normalitas bertujuan untuk mengujiapakah dalam model regresi, variabel pengganggu atau residual memiliki distribusi normal. Cara yang dapat digunakan untuk menguji apakah variabel pengganggu atau residual memiliki distribusi normal adalah dengan melakukan analisis grafik normal probability plot dan grafik histogram. Dasar pengambilan keputusan dalam uji normalitas adalah sebagai berikut:

a. Jika data tersebar disekitar garis diagonal dan mengikuti arah garis diagonal, maka model regresi memenuhi asumsi normalitas.

b. Jika data menyebar jauh dari garis diagonal dan atau tidak mengikuti arah garis diagonal, maka model regresi tidak memenuhi asumsi normalitas.

\section{Uji Heteroskedastisitas}

Menurut Ghozali (2005) uji heteroskedastisitas bertujuan mengujiapakah dalam model regresi terjadi ketidaksamaan Variance dari Residual satu pengamatan ke pengamatan yang lain. Jika Variance dari residual satu pengamatan lain tetap, maka disebut Homoskedastisitas dan jika berbeda disebut Heteroskedastisitas. Kebanyakan data crossection mengandung situasi heteroskedastisitas karena data ini menghimpun data yang mewakili berbagai ukuran (kecil, sedang dan besar) dapat dilakukan dasar analisis untuk menentukan ada atau tidaknya heterokedastisitas yaitu:

a. Jika ada pola tertentu, seperti titik-titik yang ada membentuk pola tertentu yang teratur (bergelombang, melebar kemudian menyempit), maka mengindikasikan telah terjadi heteroskedastisitas.

b. Jika tidak ada pola yang jelas, serta titik-titik menyebar di atas dan di bawah angka 0 pada sumbu Y, maka tidak terjadi heteroskedastisitas.

\section{Uji Multikolineritas}

Uji Multikolineritas bertujuan untuk menguji apakah anatara sesamavariabel bebas tidak saling berkolerasi atau dengan kata lain mempunyai hubungan linear diantara variabel bebas dalam model regresi. Apabila nilai koefisien korelasi sama dengan 1 (satu) berarti terjadi korelasi yang sempurna diantara sesama variabel bebas. Akibatnya koefisien-koefisien regresi menjadi tidak dapat ditaksir sehingga akan sulit menentukan variabel bebas mana yang mempengaruhi variabel independen, serta nilai kesalahan baku (standar eror) setiap koefisien menjadi tidak terhingga. Untuk mendeteksi multikolinieritas daoat dilakukan dengan melihat nilai tolerance dan variance inflating factor (VIF) Firdaus (2004).

Tolerance yang semakin kecil atau mendekati 0 mengindikasikan terjadinya multikolinearitas, sedangkan nilai VIF apabila < 10 mengindikasikan bahwa dalam model tidak terjadi multikolinearitas, tetapi bila VIF > 10, mengindikasikan bahwa dalam model terjadi multikolinearitas serius. Apabila dalam model ternyata terjadi multikolinearitas, maka penanggulangannya dilakukan dengan mengeluarkan salah satu variabel yang berkolerasi kuat dengan variabel lainnya.

\section{Metode Analisis Data \\ Metode Analisis}


Model umum bentuk persamaan alat Analisis Statistik Parametrik Linear Berganda (Multiple Linear Regression)menurut Rangkuti (2006) dapat digambarkan sebagai berikut:

$$
\mathrm{Y}=\mathrm{a}+\mathrm{b} 1 \mathrm{X} 1+\mathrm{b} 2 \mathrm{X} 2+\ldots \ldots \ldots .+\mathrm{bn} \mathrm{Xn}+\mathrm{e}
$$

Bila formulasi matematis Regresi Linear Berganda tersebut di aplikasikan dalam penelitian ini, maka akan diperoleh persamaan sebagai berikut:

$\mathrm{Y}=\mathrm{a}+\mathrm{b} 1 \mathrm{X} 1+\mathrm{b} 2 \mathrm{X} 2+\mathrm{e}$

Dimana:

$\mathrm{Y} \quad=$ Kinerja

$\mathrm{X} 1=$ kompetensi

$\mathrm{X} 2=$ Kecerdasan emosional

b1 b2 b3 b4 b5 = koefisien Regresi mengukur besarnya pengaruh $\mathrm{X}$ dan $\mathrm{Y}$

b1-b4 = parameter yang diukur

$\mathrm{e}=$ Error (residual)

$\mathrm{a}=$ Konstanta

\section{Pengujian Secara Simultan Untuk Hipotesis Pertama ( Uji F)}

Uji F (Uji Simultan) dilakukan untuk menguji signifikan pengaruh variabel independen terhadap variabel dependen. Dan untuk menguji keberartian dari koefisiensi regresi secara serempak digunakan dengan kaidah pengambilan kepuasan sebagai berikut sesuai hasil yang didapatkan pada perhitungan statistik menggunakan program SPSS 22.

\section{Pengujian Secara Parsial Untuk Hipotesis Kedua}

Uji t (uji parsial) adalah pengujian hipotesis yang digunakan untuk menentukan pengaruh dari masing-masing variabel (pengujian secara sendiri-sendiri) antara variabel independen dengan variabel dependen. Untuk mengkur dalam hipotesis ini dapat digunakan alat ststistik program komputer SPSS 16. Dengan kriteria dalam pengujiannya adalah sebagai berikut:

1. Jika nilai uji $\mathrm{t}<(\alpha=0,05)$ pada tingkat kepercayaan $95 \%$ maka terbukti secara parsial faktor bebas (Xi) berpengaruh tidak secara nyata (signifikan) terhadap faktor terikat $(\mathrm{Y})$ atau dengan kata lain menolak hipotesis alternative (Hi) dan menerima hipotesis mula-mula (Ho).

2. Jika nilai probabilitas uji $\mathrm{t}>(\alpha=0,05)$ pada tingkat kepercayaan $95 \%$ maka terbukti secara parsial faktor bebas $(\mathrm{Xi})$ berpengaruh secara nyata (signifikan) terhadap faktor terikat $(\mathrm{Y})$ atau dengan kata lain menerima Hipotesis alternatif (Hi) dan menolak hipotesis mula-mula (Ho).

\section{HASIL DAN PEMBAHASAN}

\section{Hasil Analisis Regresi Linear Berganda}

Model analisis regresi linear berganda digunakan untuk mengetahui pengaruh kompetensi dan kecerdasan emosional terhadap kinerja. Dalam menjawab permasalahan dan menguji hipotesis dalam penelitian ini digunakan alat analisis statistik regresi linear berganda (Multiple Linear Regresion) dengan menggunakan SPPS 22. Selanjutnya dapat dilihatpada Tabel 5 berikut ini: 
Tabel 5 Rekapitulasi Hasil Uji Regresi

\begin{tabular}{|c|c|c|c|c|c|c|}
\hline \multirow{2}{*}{\multicolumn{2}{|c|}{ Model }} & \multicolumn{2}{|c|}{$\begin{array}{c}\text { Unstandardized } \\
\text { Coefficients }\end{array}$} & \multirow{3}{*}{$\begin{array}{c}\text { Standardized } \\
\text { Coefficients }\end{array}$} & \multirow[t]{2}{*}{$\mathrm{T}$} & \multirow{3}{*}{ Sig } \\
\hline & & \multirow{2}{*}{$\begin{array}{c}\mathrm{B} \\
2,083 \\
\end{array}$} & \multirow{2}{*}{$\begin{array}{c}\begin{array}{c}\text { Std. } \\
\text { Error }\end{array} \\
.416 \\
\end{array}$} & & & \\
\hline 1 & (Constant) & & & & 5,008 & \\
\hline & Kompetensi & .610 & .106 & .763 & 2,985 & .004 \\
\hline & $\begin{array}{l}\text { Kecerdasan } \\
\text { emosional }\end{array}$ & .440 & .089 & .560 & 2.137 & .037 \\
\hline \multicolumn{3}{|c|}{$\mathrm{R}$ Square $\left(\mathrm{R}^{2}\right)$} & $=0.687$ & F-Hitung & & $=12.501$ \\
\hline \multicolumn{3}{|c|}{ Adjusted R Square } & $=0.564$ & Konstanta & & $=2.083$ \\
\hline \multicolumn{3}{|c|}{ Multiple R } & $=0.536$ & Sig.F & & $=0.000$ \\
\hline
\end{tabular}

Sumber: data di olah

Hasil analisis regresi linear berganda dalam Tabel 5.13 diatas, kemudian dimasukkan kedalam model persamaan regresi linear berganda berikut:

$$
\mathrm{Y}=2.083+0,610 \mathrm{X}_{1}+0,440 \mathrm{X}_{2}
$$

a. Nilai konstanta a adalah 2,083 yang menunjukkan bahwa variabel kompetensi dan kecerdasan emosional $\left(\mathrm{X}_{1}\right.$ dan $\left.\mathrm{X}_{2}\right)$ berpenngaruh simultan terhadap variabel kinerja (Y). Berarti jika variabel kompetensi dan kecerdasan emosional berubah/konstan maka kinerja akan mengalami peningkatan pula

b. Nilai koefisien regresi $b_{1}$ adalah 0,610 yang menunjukkan bahwa variabel kompetensi $\left(\mathrm{X}_{1}\right)$ berpengaruh positif terhadap kinerja. Berarti apabila kompetensi meningkat maka kinerja akan meningkat pula.

c. Nilai koefisien regresi $b_{2}$ adalah 0,440 yang menunjukkan bahwa variabel kecerdasan emosional $\left(\mathrm{X}_{2}\right)$ berpengaruh positif terhadap kinerja pegawai Hal ini menunjukan apabila kecerdasan emosional meningkat maka kinerja pegawai akan mengalami peningkatan

d. Persamaan regresi berganda adalah $\mathrm{Y}=2,083+0,610 \mathrm{X} 1+0,440 \mathrm{X} 2$. Persamaan regresi tersebut menunjukkan bahwa setiap kenaikan skor kompetensi sebesar 1 unit akan menyebabkan kenaikan skor kinerja pegawai sebesar 0,610 unit dan kenaikan skor kecerdasan emosional sebesar 1 unit akan menyebabkan kenaikan skor kinerja pegawai sebesar 0,440 unit pada konstanta 2,083

Persamaan regresi diatas menunjukan bahwa variable independen yang berpengaruh terhadap kinerja pegawai adalah variable kompetensi (X1) dan kecerdasan emosional (X2). Sementara itu nilai koefisien korelasi (Multiple-R) yang diperoleh 0,536, jika ditafsirkan nilai tersebut maka dapat dikatakan bahwa terjadi hubungan antara kedua variabel kompetensi dan kecerdasan emosional terhadap kinerja pegawai dengan nilai hubungan sebesar 53,6\% , sehingga kedua variabel independen tersebut layak untuk diteliti.

\section{Hasil Pengujian Hipotesis}

\section{Uji Simultan (Uji F)}

Berdasarkan perhitungan menunjukan bahwa angka F-hitung sebesar 12.501 dengan tingkat signifikan sebesar 0,000 < a 0,05. Maka Ho ditolak dan Ha diterima. Artinya Variabel kompetensi dan kecerdasan emosional secara serempak berpengaruh terhadap kinerja pegawai Kantor Badan Perencanaan Pembangunan Daerah (BAPPEDA) Provinsi Sulawesi Tengah

Persentase pengaruh variable kompetensi dan kecerdasan emosional terhadap nilai variable kinerja pegawai ditunjukan oleh besarnya koefisien determinasi ( $R$ Square), hasil perhitungan diperoleh besarnya koefisien determinasi ( $\mathrm{R}$ Square) adalah 0,687 , artinya pengaruh variable independen yang 
terdiri dari kompetensi dan kecerdasan emosional terhadap perubahan nilai variable dependen yaitu kinerja pegawai adalah $68,7 \%$ dan 31,3\% dipengaruhi oleh variable lain selain dari variable indevenden yang digunakan.

\section{Uji Parsial (Uji t)}

Berdasarkan hasil olahan data penelitian, nilai probabilitas signifikasi variable kompetensi (X1), variable kecerdasan emosional (X2), Dari kedua variabel memiliki nilai lebih kecil dari taraf signifikasi yang disyaratkan yaitu 0,05 . Secara statistic dari kedua variabel dalam penelitian ini secara parsial berpengaruh positif dan signifikan terhadap kinerja pegawai Kantor Badan Perencanaan Pembangunan Daerah Provinsi Sulawesi Tengah.

\section{KESIMPULAN DAN SARAN \\ Kesimpulan}

Berdasarkan hasil pembahasan di atas Variabel Kompetensi dan kecerdasan emosional berpengaruh signifikan baik secara serempak maupun secara parsial terhadap kinerja pegawai kantor Badan Perencanaan Pembangunan Daerah (BAPEDDA) Provinsi Sulawesi Tengah

\section{Saran}

Berdasarkan kesimpulan yang dapat diambil dari uraian dan pembahasan pada bab-bab sebelumnya maka penulis memberikan saran yang mungkin bermanfaat untuk meningkatkan kinerja pegawai kantor Badan Perencanaan Pembangunan Daerah (BAPPEDA) Provinsi SulawesiTengah sebagai berikut:

Kompetensi dan kecerdasan emosional pegawai kantor Badan Perencanaan Pembangunan Daerah (BAPPEDA) Provinsi Sulawesi Tengah harus lebih ditingkatkan lagi khususnya dalam hal pengetahuan tentang pekerjaan serta kemampuan untuk menyesuaikan diri terhadap kondisi apapun yang berhubungan dengan pekerjaan Sehingga mampu meningkatkan kinerja dari setiap pegawai.

\section{REFERENSI}

Anwar Prabu Mangkunegara. 2005. Evaluasi Kinerja SDM. Bandung: Refika Aditama.

Goleman, D., 2006. Emotional Intelligence. (Terjemahan T Hermaya)PT Gramedia Pustaka Utama, Jakarta.

Ghozali, Imam. 2005. Aplikasi Analisis Multivariate dengan SPSS. Semarang: Badan Penerbit UNDIP.

Moeheriono, 2012, Pengukuran Kinerja Berbasis Kompetensi, edisi revisi, cetakan pertama, Penerbit : Raja Grafindo Persada, Jakarta

Palan, R. 2007. Competency Management; Teknik Mengimplementasikan Manajemen SDM Berbasis Kompetensi Untuk Meningkatkan Daya Saing Organisasi. Penerjemah: Octa Melia Jalal. Jakarta : PPM.

Spencer, Lyle M. and Signe M. Spencer. 1993. Competence Work: Model for Superior Performance. John Wiley and Sons, Inc

Sutrisno, Edy, 2009, Manajemen Sumber Daya Manusia, edisi pertama, cetakan pertama, Penerbit : Kencana Prenada Media Group, Jakarta

Suyadi Prawirosentono. 2008. Manajemen Sum berdaya Manusia Kebijakan Kinerja Karyawan. Yogyakarta: BPFE. 
Sugiyono. 2014 . Metode Penelitian Kuantitatif Kualitatif dan R\&D. Bandung : Alfabeta, cv Wibowo. 2009. Manajemen Kinerja. Jakarta : PT Raja Grafindo Persada. 